\title{
Tasks of the State and Role of Social Law in the Field of Social Welfare
}

\author{
Dr. iur. Artur Kokoszkiewicz \\ College of Entrepreneurship and Administration in Lublin, Poland \\ artur.kokoszkiewicz@gmail.com
}

\begin{abstract}
The article deals with the issue of state tasks in social sphere and the role of social law in shaping social protection. This is a common subject, as it concerns every legal order of modern democratic legal states (the Western model). Interesting are also the functions that social law has met in the past and present. The article presents legal approach; although due to the importance and universality of the subject, the approach to sociology of law, history and political science has also been hinted at. The first part of the article presents the concept of "social welfare" and social law. The second part focuses on historical outline that helps explain the phenomenon of social welfare being researched. It has been discovered that social law has a very long history, probably related to the beginnings of statehood. Subsequently, a few comments on the tasks of modern democratic legal state of the Western model have been discussed, indicating the diagram of typology of political doctrines showing a number of dependencies. Finally, social welfare models have been described, adding remarks about the role of social law in this area.
\end{abstract}

Keywords: social welfare, social law, state tasks.

\section{Introduction}

Conducting scientific research on the tasks of states in social welfare sector and the role of social law in shaping these tasks, it must be scientifically explained what social care is, why it was created, why it is exercised in various countries, and what determines the form of its exercise. This is a research problem of interest not only in legal science, but also in principle interdisciplinary. Social welfare can be (and is) the subject of interest, for example, in sociology, economics, psychology or political science. Social welfare and social 
law regulating it are present in every state of our cultural circle (Dziewięcka-Bokun, 2000). Significant financial resources are allocated for the implementation of care tasks, which increases the importance of the research problem. Therefore, the article comments on its contributing nature, the title issue regarding the tasks of the state and the role of social law in the field of social welfare.

\section{Concept of Social Protection and Social Law}

Care stands for caring for someone, satisfying someone's needs, guarding someone or something, supervision, custody, guardianship; in addition to care, the term "social welfare" is distinguished, which in colloquial sense means a local institution dealing with environmental aid (Sikorska-Michalak, Wojniłko, 2000). Care is a caring conscientious care for satisfaction of someone's needs, guarding someone or something (Zgółkowa, 2000). Encyclopaedia Britannica, in turn, includes the term "social and welfare services", which can be interpreted as social services, the connotation of which complies with the social welfare discussed. Social care cannot be clearly defined, but it can be assumed that it is based on three main pillars of activity: remedial, preventive and supportive. It is also worth noting that in 1967 a definition of experts of the United Nations (UN) was created in which social assistance is seen as a set of factors that help individuals, groups and societies overcome difficult social situations, the source of which lies in change. In communism, for example, Polish or Latvian, it seems that there was no place for social protection, because the socio-political system then assumed (theoretically and in fact false) full satisfaction of society. There was therefore no need to redistribute income and to provide social welfare, because everyone, of course in theory, was satisfied.

Summarising, we can assume that social care is based on three main principles:

1. the purpose of its programmes is to guarantee minimum income standards for people whose incomes are insufficient;

2. these persons have no other means or access to other means to be able to provide themselves with a minimum income standard;

3. the purpose of these programmes is not to increase the dependence of people on programmes, but to include measures to encourage self-sufficiency and independence (Eardley, 1996).

It seems that in the system of law, which can be referred to as social law (which will be part of the administrative law), there is a number of legal institutions that are part of the social protection (aid) in question. These will include, for example, various types of benefits, child benefits, material support (for example in the form of food or clothes), non-material support (for example, counselling or psychological assistance). 


\section{Historic View}

Social assistance is not a modern invention. Aristotle in work Politics notes that state education of children of fallen soldiers was ensured. In Roman times, cereal was distributed, and in 779, Charlemagne imposed a tax on bishops, princes and vassals, and he obtained public funds for the protection of the poor (Zamorska, 2010). A common form of help to the poor was giving away grain from state granaries at low prices, and sometimes free of charge. Many Romans used this right. During the times of Julius Caesar, their number reached about 300,000 people. In the second century BC, the poor Romans also received olive oil for free, and on special occasions - clothing (e.g., triumphal entry of chiefs) (Mielczarek, 2006).

As one of the reasons for such social protection is mentioned the necessity of helping another person, which is inscribed in the system of law and human values (Sierpowska, 2008). The above claim could be attributed to the common denominator of the "humanistic" origin of social welfare.

However, in Polish legal literature before World War II, it was pointed out, that from a purely egotistic drive, a man began to help his neighbour. Experience has taught that it is necessary to help one's neighbour in disguise to receive such help in the event of misfortune from him. Being aware that old age is unavoidable for every human being, they began to look after the elderly (Zawadzki, 1935). Friedrich von Hayek stated that the need for social care institutions in industrial society is unquestionable; even for protection against acts of desperation on the part of the poor (Zamorska, 2010). Thus, the essence of the above view is that social welfare is a stabilising factor as an element of social policy of the state.

The reasons for shaping social welfare can therefore be seen on the side of the state apparatus, which was vitally interested in having tools to shape the situation the social subordination of society.

The above helps explain the complex nature of the reasons accompanying the development of social welfare. In social care pedigree, one can distinguish (obviously by making a significant simplification) two leading factors: either humanistic or pragmatic in nature. This is even more highlighted by social policy implemented by the EU Member States and its application of social welfare.

\section{Tasks of Modern State}

The current legal tasks of the state include education, higher education, internal and external safety, health care, courts and prosecutors, government and local government administration, state-owned enterprises, agricultural production, trade, services, etc.

The tasks of the state are the result of elementary assumptions that this state accepts. The responsibilities of the modern democratic state of law depend on the state model that the specific state implements. One can point at two opposing models of states perceived through the prism of the tasks assigned to them; the minimum and the maximum state model. 


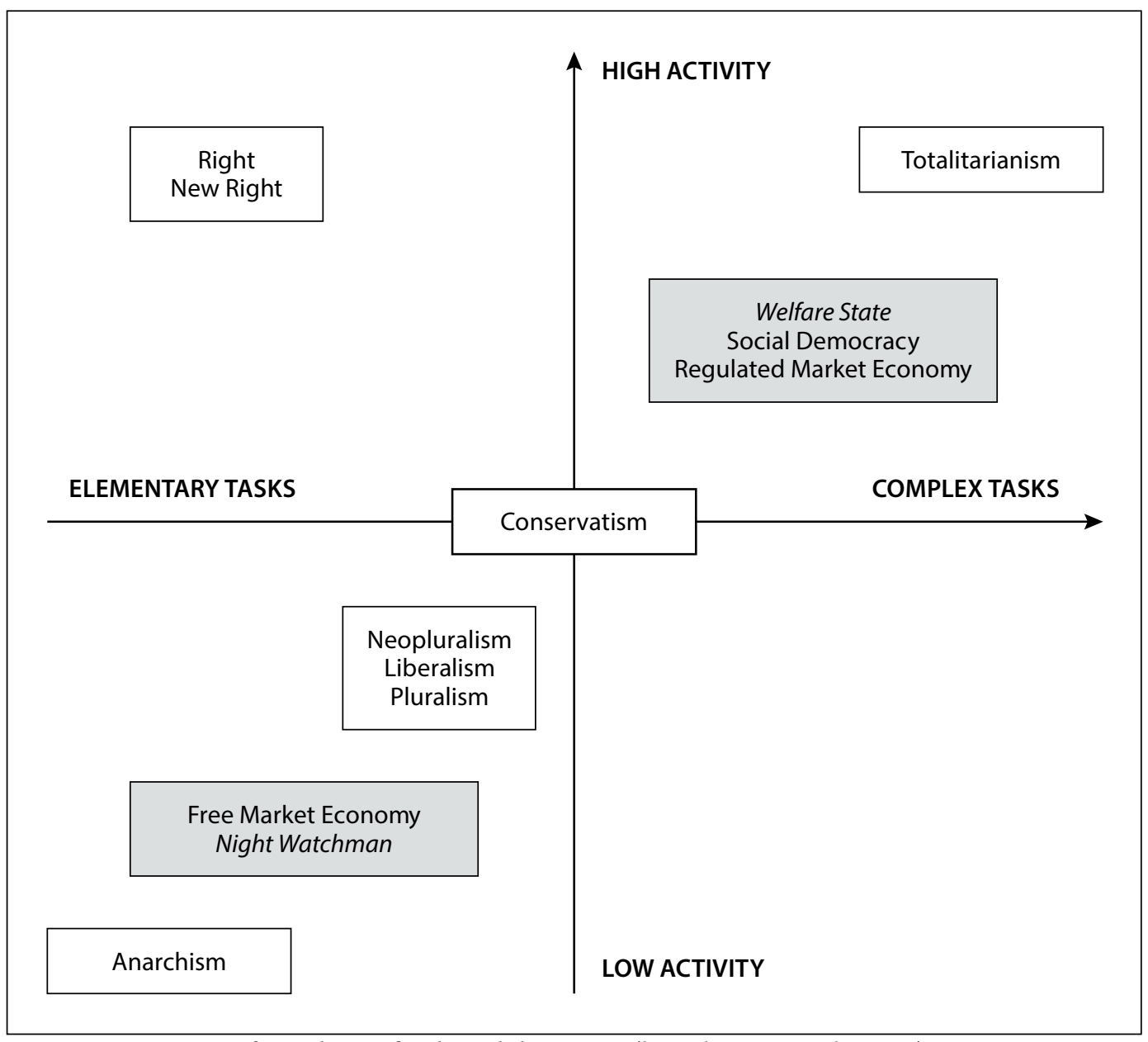

Figure. 1. Diagram of typology of political doctrines (based on Szostak, 1998)

This is the scheme of the typology of political doctrines. Dependencies on two axes can be observed: vertical, where we have state activity in the tasks we perform, from small to large, and horizontal, where we have state tasks, their size, number, from small (elementary tasks) to large (tasks extended) (Held, 2010). Despite its simplification, Figure 1 allows to notice the necessary difference (Żmigordzki, 1987). Depending on variables, different typologies of political doctrines will be dealt with. From the extreme, anarchism, where there are no tasks thus they are not performed; by the doctrines of a free market economy or state as a night watchman; by liberal doctrines, conservatism, welfare state, social democracy with regulated market economy to the next extreme example - totalitarianism - where tasks are carried out in a very complex scope and with high activity (intensity). 
In the case of a minimal state, one can recall the views of Adam Smith contained in the Inquiry into the Nature and Causes of the Wealth of Nations. Smith writes that under the system of natural freedom, the ruler will only have to fulfil three duties. They are, however, duties of great importance, but for this, they are clear and widely understood. First, this is the duty to protect society against rape or invasion by other independent societies. Second, it is the duty to defend any member of society as far as possible from injustice and oppression from all other members of society; that is, the obligation to establish a proper administration of justice. Third, the obligation to establish and maintain certain public facilities, the establishment and maintenance of which can never be in the interest of the individual or a small number of units (Smith, 1954). A similar position can be found, for example, with Milton Friedman (Ptak, 2008) or Robert Nozick (Nozick, 1974) - well-known libertarians and anarchists.

A contrario, a group of maximum state models will be the opposite of the minimal state. In particular, the state will cover many areas with its interference, taking on a paternalistic role. Hagen Schulze, discussing the medieval state of Frederick II, writes that the state wanted to be ubiquitous. Doctors, surgeons, apothecaries, and lawyers had to be approved by the state; their fees were set by the administration. The production and sale of medicines were bureaucratically supervised, and their prices were set out in regulations. Every craft in all its aspects was regulated by laws, everyday life of subjects was rationed, up to regulations concerning the purity of water and air. The state even interfered in private lives of the subjects; marriages with foreigners were forbidden, and marriages of knights and barons required the consent of a ruler. The author states, this was a state of absolutist administration and law (Schulze, 2012).

The maximum model, where the state intervened in many areas of social life is also known for our Polish and Latvian historical experiences.

In Poland and Latvia, for many years we have had a dominant role of the state in areas that we consider to be private today. State factories, industrial production, health care or education (only) and even agricultural production (state agricultural farms), although in this respect, derogations were allowed in Polish communism allowing for private property. Part of the land and farms remained in the hands of the owners.

It can be assumed that the model of a minimal state (or of a liberal character) assumes that only a few tasks are carried out by the state. It seems that these will be tasks necessary for functioning of the state, for example, maintaining the army, law enforcement forces or administration of justice. The state is an instrument of protection, a tool enabling the realisation of particular interests of individuals constituting society. Its opposite is the model of the maximum state, that is, a state that performs numerous tasks, interferes in a number of areas of social life. The state is, therefore, the organiser of social life, which requires individuals to submit themselves to the common goal (which may limit or prevent the realisation of particular interests of individuals constituting society). 


\section{Models of Social Care}

In social care models, the polar division is also outlined: from the minimal model, where social care is largely left in the sphere of charity, to the maximum model, where the state is the organiser of social life and through its institutions redistributes goods to meet citizens' needs.

In the elementary model, the main subject of social welfare is the family, not the state. Social problems are solved at the lowest level, and social assistance is based on charity. The elementary model can be compared to primary social care, which goes back to the principles of private charity.

The "measure" model is sometimes called, among others, "corporate", "conservative", or "motivational". The basic feature of such a model should be the creation of a specialised administrative apparatus responsible for the functioning of social welfare. On the one hand, there are elements of paternalism consisting in the organisation of social welfare by the state. On the other hand, satisfying the human needs follows the criterion of seniority, merit and efficiency.

At the other extreme are the maximum models called "caring", "social democratic" or "Scandinavian" models. The model of this group is characterised by a high degree of paternalism of the state and interference in the social sphere. It is about striving for the state to provide employment and a high level of social services. Social services are extensive and specialised. Social protection covers all citizens from birth to death.

It is worth mentioning that for the implementation of any of the solutions discussed, there is a need for a law. It is the law that is the regulator of social life in this case. It is in law that one will find their normative stipulation of social welfare system, its organisation, benefits, amount, method of payment, etc. As stated, administrative and social law as a rule remains public.

\section{Conclusion}

Models of social welfare serve as one of the tasks of the state. Depending on the model of functioning adopted in a specific country, its tasks - and hence social care can be implemented in a more or less intensive way. Since the article discusses democratic states of the rights of the Western model, one can make the following conclusion (final proposal): social welfare is an element (tool) of social function of every democratic state of law (Dziewięcka-Bokun, 2000).

Every country of this type deals with social protection to a lesser or greater extent. Therefore, countries that provide social welfare state are referred to as welfare states. Recognising the positive, it must be admitted that in contemporary legal and sociological or political thought, the welfare state criticism is dominating (Fukuyama, 2000).

It has been acknowledged that excessive social spending does not have a good impact on society and leads to many pathologies. It seems that criticism of the state's excessive protection is part of the so-called migration crisis that is currently being 
dealt with in the European Union. Wandering of peoples, among others from Africa or the Middle East in search of social care, do not arouse too much enthusiasm of societies.

David Held, who in Democracy Models constructs the theory of an overloaded state (the crisis of the liberal-democratic welfare state regime), has expressed an interesting view in this respect (Held, 2010). He points to the following process: the starting point (welfare state) (1) increases the expectations of citizens (2), which in turn leads to a "crisis of authorities" and increases the aspirations for "even more" (3). Subsequently, social groups are more and more boldly pushing for the implementation of the fragmented goals, forcing the country to take advantage of their political solutions (4). Politicians of all parties seek ad hoc political profits (5), which in turn leads to a further increase in citizens' expectations (6). Governments have a delay policy (7), which increases the number of overdeveloped state agencies (8), which means that the state is losing its ability to manage effectively (9). The ability to generate wealth through the private sphere breaks down (10) and the vicious circle starts, returning to point four (11), or forcing further political solutions by pressure groups. If Held's "vicious circle" is not interrupted during the cyclical repetition of the scheme, the state awaits a multifaceted annihilation (economic, legal, social, ideological).

Thus, an open question arises, where the point of the model is located in individual countries and whether there is a chance to break the cycle. However, this is a topic for successive scientific texts.

\section{Valsts uzdevumi un sociālo tiesību nozīme sociālās labklājības jomā}

\section{Kopsavilkums}

Jautājums par valsts uzdevumiem sociālajā jomā un sociālo tiesību lomu sociālās aizsardzības veidošanā attiecas uz ikvienas mūsdienu demokrātiski tiesiskas valsts (Rietumu modeḷa) tiesisko kārtību. Rakstā tiek aplūkota ne tikai juridiskā pieeja šim jautājumam, bet arī tiesību sociologiijas, vēstures un politologiijas aspekti, n,emot vērā to, kā sociālās tiesības tikušas ievērotas senāk un kā tās tiek nodrošinātas mūsdienās.

Rakstā ir aplūkots sociālās labklājỉbas un sociālo tiesību jēdziens, sniegts vēsturiskais izklāsts, kas palīdz izskaidrot sociālās labklājības fenomenu, un konstatēts, ka sociālajiem likumiem ir l̦oti ilga vēsture, kas, iespējams, ir saistīta ar valstiskuma pirmsākumiem. Rakstā sniegti komentāri par mūsdienu demokrātiski tiesiskas valsts (Rietumu modeḷa) uzdevumiem sociālajā jomā, kā arī aplūkota politisko doktrīnu tipologiija. Visbeidzot, tiek apskatīti sociālās labklājības modeḷi, aktualizējot sociālo tiesību lomu šajā jomā.

Atslēgvārdi: sociālā labklājība, sociālie likumi, valsts uzdevumi. 
Artur Kokoszkiewicz. Tasks of the State and Role of Social Law in the Field of Social Welfare

\section{References}

1. Dziewięcka-Bokun, L. 2000. Systemowe determinanty polityki społecznej (Eng. Systemic Determinants of Social Policy). Wrocław, 131-132.

2. Eardley, T. 1996. Social Assistance in OECD Countries: Synsthises Report. London, 47.

3. Fukuyama, F. 2000. The Great Disruption: Human Nature and the Reconstitution of the Social Order. Warszawa, 58.

4. Held, D. 2010. Models of Democracy. Kraków, 248-250.

5. Kokoszkiewicz, A. 2015. Opieka społeczna jako zadanie państwa. Studium teoretycznoprawne (Eng. Social Welfare as a Task of the State. Theoretical and Legal Study). Lublin.

6. Mielczarek, A. 2006. Polska pomoc społeczna: doświadczenia historyczne (Eng. Polish Social Assistance: Historical Experience). Toruń, 9.

7. Nozick, R. 1974. Anarchy, State and Utopia. Oxford, 26-33.

8. Ptak, P. 2008. Ile państwa w gospodarce?: Milton Friedman o ekonomicznej roli państwa (Eng. How much State in the Economy?: Milton Friedman on the Economic Role of the State). Warszawa, 43.

9. Schulze, H. 2012. Państwo i naród w dziejach Europy (Eng. The State and the Nation in the History of Europe). Warszawa, 27.

10. Sierpowska, I. 2008. Państwo wobec pomocy społecznej. Wrocławskie studia erazmiańskie: Państwo - koncepcje i zadania (Eng. State towards Social Assistance. Wrocław Erasmus Studies: State - Concepts and Tasks). Wrocław, 139.

11. Sikorska-Michalak, A. Wojniłko, O. 2000. Słownik współczesnego języka polskiego, III (Eng. Dictionary of contemporary Polish language, III). Kraków, 226.

12. Smith, A. 1954. An Inquiry into the Nature and Causes of the Wealth of Nations. 2. Warszawa, 339-340.

13. Szostak, W. 1998. Problem "ciężaru państwa”: optymalizacja roli państwa liberalno-demokratycznego (Eng. The problem of the "burden of the state": optimising the role of the liberal-democratic state). Kraków, 182-195.

14. The New Encyclopaedia Britannica in 30 Volumes: Macropaedia volume 16. 1975. Chicago, London, Toronto, Geneva, Sydney, Tokyo, Manila, Seoul, Johannesburg.

15. Zamorska, K. 2010. Prawa społeczne jako program przebudowy polityki społecznej (Eng. Social rights as a programme of remodelling social policy). Wrocław, 206.

16. Zawadzki, J. 1935. Zasady opieki społecznej (Eng. Principles of social welfare). Warszawa, 8-9.

17. Zgółkowa, H. 2000. Praktyczny słownik współczesnej polszczyzny. T. 26 (Eng. A practical dictionary of contemporary Polish, vol. 26). Poznań.

18. Żmigrodzki, M. 1987. Współczesne państwowe systemy polityczne (Eng. Contemporary state political systems). Lublin. 